\title{
Modulation of host cell signal transduction pathways by Helicobacter pylori infection
}

\author{
Peter JM Ceponis $\mathrm{PhD}^{1,3}$, Nicola L Jones MD PhD FRCPC ${ }^{2,3}$
}

PJM Ceponis, NL Jones. Modulation of host cell signal transduction pathways by Helicobacter pylori infection. Can J Gastroenterol 2005;19(7):415-420.

Bacterial pathogens modulate host cell signal transduction responses to establish infection and cause disease. The purpose of the present summary, first presented at the Canadian Helicobacter Study Group meeting, is to discuss current knowledge of specific Helicobacter pylori factors, including the vacuolating cytotoxin, cytotoxin-associated gene A and the type four secretion system encoded by the cytotoxinassociated gene pathogenicity island and review the host cell signal transduction cascades that they modulate.

Key Words: Epithelium; H pylori; Signal transduction

\section{La modulation des voies de transduction du signal des cellules hôtes par l'infection à Helicobacter pylori}

Les pathogènes bactériens modulent les réponses de transduction du signal des cellules hôtes pour établir une infection et provoquer une maladie. Le présent résumé, présenté pour la première fois à la réunion du groupe d'étude canadien de l'Helicobacter, vise à aborder les connaissances actuelles sur des facteurs précis de l'Helicobacter pylori, y compris la cytotoxine vacuolante, le gène $\mathrm{A}$ associé à la cytotoxine et le système de sécrétion de type quatre codé par l'îlot de pouvoir pathogène du gène associé à la cytotoxine, et à examiner les cascades de transduction du signal des cellules hôtes qu'elles modulent.

\section{MODULATION OF HOST CELL SIGNALLING BY BACTERIAL PATHOGENS}

Current evidence suggests that bacterial pathogens establish infection and cause disease by modulating host cell signal transduction responses. Indeed, disrupting the ability of pathogens to modulate host signalling cascades can alter the sequelae of infection. For example, treating mice with Gram-positive lipoprotein leads to cytokine production and induces shock; effects that are ameliorated by cotreatment with a monoclonal antibody directed against the host cell lipoprotein receptor, Toll-like receptor (TLR)-2 (1). Also, humans suffering from traveller's diarrhea treated with a calmodulin kinase inhibitor experience a decreased severity and duration of the disease (2). In addition, pharmacological inhibition of the mitogen-activated protein kinases (MAPKs) p38 and c-jun $\mathrm{N}$-terminal kinase proved safe and effective for treatment of Crohn's disease in humans (3). Such observations indicate that knowledge of signalling cascades can facilitate therapeutic intervention; however, a sound understanding of host cell signalling pathways modulated by specific bacterial factors is first required. The purpose of the present summary, first presented at the Canadian Helicobacter Study Group meeting, is to discuss current knowledge of specific Helicobacter pylori factors and the host cell signal transduction cascades they modulate. Putative host cell signal transduction pathways modulated by $\mathrm{H}$ pylori infection are shown in Figure 1 .

\section{ADHESION TO HOST EPITHELIAL CELLS}

Bacterial adhesion to host cells is often a critical step for microbial infections as a prerequisite to colonization, internalization or the delivery of toxins (4). In vivo studies (5) to delineate tissue tropism of $\mathrm{H}$ pylori have shown that the organism binds specifically to gastric epithelial cells and in areas of gastric metaplasia, with multiple, redundant bacterial adhesins likely participating in adhesion (6).

Several laboratories have delineated bacterial adhesins and their respective host cell receptors (Table 1). Although adhesinreceptor binding at the host cell surface probably initiates host cell signalling casacades, the precise events triggered by such binding are not characterized. For example, $H$ pylori heat shock protein 60 binds host cell sulfogalactosylceramide (7), but whether this is involved in heat shock protein 60-mediated activation of nuclear factor-kappa $\mathrm{B}(\mathrm{NF}-\mathrm{\kappa B})$ and interleukin (IL)-6 secretion through TLR-2 (8) is unknown.

Delineation of host receptors for bacterial adhesins remains a priority. For example, it was recently discovered that expression of trefoil factor- 1 in the mucous layer of the stomach mirrors the tissue tropism of $H$ pylori (9). Determination of the bacterial adhesin involved is an important future goal.

Of note, $H$ pylori mainly reside in the mucous layer of the human stomach (10). Thus, bacterial adhesion to multiple host cell receptors, either secreted in the mucous or attached to the plasma membrane, in either healthy or inflamed gastric tissues, likely serves to mediate the chronic colonization observed following $\mathrm{H}$ pylori infection.

\section{H PYLORI-INDUCED NF-KB ACTIVATION}

$H$ pylori infection induces secretion of IL-8 from human gastric epithelial cells $(11,12)$, a process requiring NF- $\mathrm{kB}$ activation.

Departments of ${ }^{1}$ Laboratory Medicine $\mathbb{E}$ Pathobiology and ${ }^{2}$ Paediatrics, University of Toronto; ${ }^{3}$ Research Institute, Hospital for Sick Children, Toronto, Ontario

Correspondence: Dr Nicola L Jones, Hospital for Sick Children, 555 University Avenue, Room 8409, Toronto, Ontario M5G 1 X8.

Telephone 416-813-7734, fax 416-813-6531, e-mail nicola.jones@sickkids.ca 


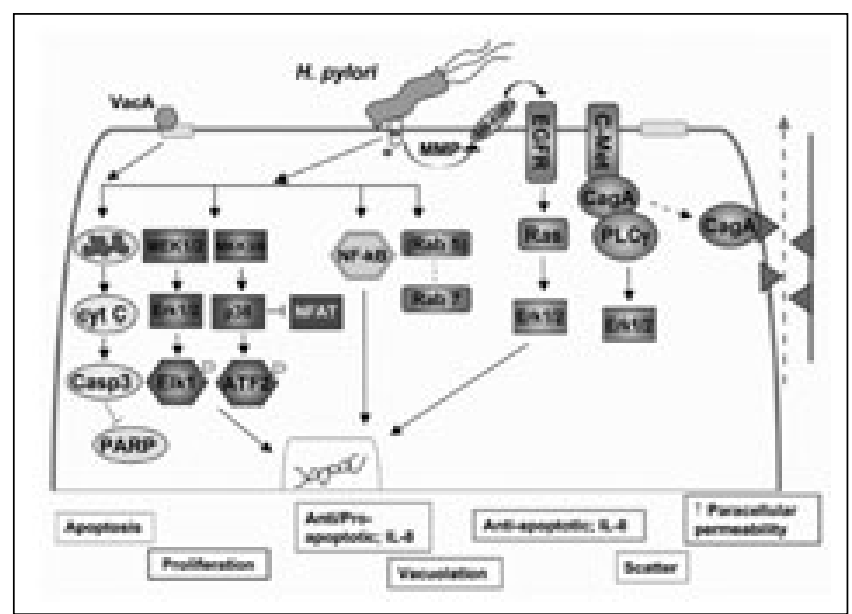

Figure 1) Putative host cell signal transduction pathways modulated by Helicobacter pylori infection. Select examples of specific bacterial factors that activate host cell signalling cascades to elicit functional effects (outlined beneath the pathways). From left to right: H pylori vacuolating cytotoxin (VacA) (hexagon) induces mitochondrial membrane damage, ultimately leading to caspase-3 (Casp3) activation, inhibition of poly (ADP-ribose) polymerase (PARP) and apoptosis. Furthermore, VacA interacts with host cell plasma membrane microdomains enriched with cholesterol to exert functional effects. Next, activation of mitogen-activated protein kinase cascades, including extracellular signal-regulated kinase 1/2 (Erk1/2) and p38, may be involved in causing proliferation of host cells, while nuclear factor-kappa B (NF- $\mathrm{B} B$ ) activity may exert both pro- and antiapoptotic activity, and is involved with induction of interleukin (IL)-8 secretion. Host cell vacuolation is achieved mainly through activation of the small GTPase Rab7. In addition, H pylori injects cytotoxin-associated gene A (CagA) into host cells via a type IV secretion system. CagA is then tyrosine phosphorylated and induces multiple signalling cascades by affecting host cell surface receptors, including the epidermal growth factor receptor (EGFR) and c-Met receptor, to ultimately cause IL-8 secretion and cell scattering, respectively. CagA also binds to Src homology-2-containing phosphatase and to the tight junction proteins zonula occludens 1 and junctional adhesion molecule to cause cytoskeletal changes and increased paracellular permeability, respectively. cyt C Cytochrome C; HB-EGF Heparinbinding EGF; MMP Metalloproteinase; NFAT Nuclear factor of activated T cells; PLC $\gamma$ Phospholipase C gamma

The proximal aspect of this pathway begins with functional tumour necrosis factor receptor-associated factor- 2 and factor- 6 adapter proteins, which are necessary to activate
$\mathrm{NF}-\kappa \mathrm{B}$-inducing kinase. NF- $\kappa \mathrm{B}$-inducing kinase subsequently phosphorylates inhibitory (I) $\kappa B$ kinase $-\alpha$ and $-\beta$ which, when activated, phosphorylate $\mathrm{I} \kappa \mathrm{B} \alpha$, leading to degradation of $\mathrm{I} \kappa \mathrm{B} \alpha$ by the proteosome. NF- $\kappa \mathrm{B}$ is then released from its complex with $\mathrm{I} \kappa \mathrm{B} \alpha$, enabling the transcription factor to translocate from the cytoplasm to the nucleus and bind DNA (13).

Proinflammatory mediators, including bacteria and their products, can lead to the activation of NF- $\mathrm{kB}$. This recognition of common microbial components, or pathogen-associated molecular patterns, is achieved through either cell surface expressed TLRs or intracellular nucleotide-binding oligomerization domain protein (Nod)1 and Nod2 receptors (14). Subsequent signal transduction initiated by the different TLR or Nod ligands can overlap, involving recruitment of IL-1 receptorassociated kinase- 1 and -4 via an adaptor protein, such as myeloid differentiation factor-88, with subsequent activation of MAPKs followed by activation and nuclear translocation of NF- $\mathrm{BB}$ (15). However, the signalling pathways can vary based on the TLR or Nod activated, and on the adaptor molecules expressed in a particular cell type, leading to distinct gene expression effects.

$\mathrm{H}$ pylori flagellin is 1000 -fold less potent at activating gastric epithelial cell TLR-5 than is flagellin of Salmonella typhimurium (16). In addition, blockade of TLR-4 using a monoclonal antibody did not prevent $H$ pylori-induced IL-8 secretion from gastric epithelial cells (17). However, the absence of cytotoxin-associated gene (cag) E abolishes the ability of $\mathrm{H}$ pylori to induce NF- $\mathrm{\kappa B}$ activity and IL-8 secretion from epithelial cells, but not from monocytes $(18,19)$. Moreover, a cag pathogenicity island (PAI)-positive type I H pylori strain modulates expression of many genes in epithelial cells, as determined by microarray analysis, while gene expression in epithelial cells infected with an isogenic mutant of $H$ pylori lacking the cag PAI more closely resembled uninfected cells (20). Taken together, this evidence suggests that $H$ pylori does not activate NF- $\mathrm{KB}$ through ligation of TLRs on epithelial cells, but that the cag PAI is required.

\section{VACUOLATING CYTOTOXIN}

Vacuolating cytoxin (VacA) activity is produced by approximately $50 \%$ of $\mathrm{H}$ pylori isolates, but the vacA gene is encoded in the genome of all $H$ pylori strains (21). Activity of the protein toxin is dependent on allelic variations in the gene, in which vacA alleles posses either signal region s1 or s2, and

\section{TABLE 1}

Adhesins of Helicobacter pylori and their host cell receptors

\begin{tabular}{|c|c|c|}
\hline Reference & Bacterial adhesin & Host cell receptor \\
\hline Gold et al (83) & Not characterized (employed whole, live $H$ pylori) & Phosphatidylethanolamine and the glycolipid gangliotetraosylceramide \\
\hline Valkonen et al (84) & $\sim 25 \mathrm{kDa}$ outer membrane protein & Sialic residues in the basement membrane protein laminin \\
\hline Huesca et al (7) & Bacterial heat shock protein 60 & Sulfogalactosylceramide \\
\hline Ilver et al (85) & $\begin{array}{l}\text { Outer membrane protein: blood-group antigen- } \\
\text { binding adhesin }\end{array}$ & Lewis B-type antigen (on red blood cells, gastric epithelia) \\
\hline Linden et al (86) & Blood-group antigen-binding adhesin & Mucin 5AC harbouring Lewis B-type antigen \\
\hline \multicolumn{3}{|c|}{ Van de Bovenkamp et al (87) } \\
\hline Mahdavi et al (88) & $\begin{array}{l}\text { Outer membrane protein: sialic acid-binding } \\
\text { adhesin }\end{array}$ & Sialylated glycoconjugates expressed by inflamed gastric mucosa \\
\hline Su et al (17) & Not characterized (employed whole, live $H$ pylori) & Toll-like receptor-4 \\
\hline Clyne et al (9) & Not characterized (employed whole, live $H$ pylori) & Trefoil factor-1 \\
\hline
\end{tabular}


midregion $\mathrm{m} 1$ or $\mathrm{m} 2$ (in all possible combinations), and where $\mathrm{s} 1 / \mathrm{m} 1$ represents the most active toxin $(21,22)$. Clinical studies have associated higher VacA activity with more severe disease (23). However, this observation remains controversial, with variability depending on the human populations under study (24). Furthermore, in most studies (25) involving the pediatric population, there has been a lack of association between vacA alleles and disease outcome.

Nevertheless, production of the VacA toxin elicits an antibody response in infected humans, and these antibodies neutralize toxin activity in vitro (26). Moreover, a murine model of $H$ pylori infection suggests that VacA production is advantageous to colonization of the stomach (27), and gastric administration of recombinant $\mathrm{Vac} A$ to mice induced gastric ulcerations and lesions similar to those seen in infected humans (28). This damage occurs through VacA-mediated activation of its putative receptor, protein tyrosine phosphatase type-Z, and this damage was mimicked by addition of the natural ligand, pleiotrophin (29). Other putative VacA receptors include receptor-like protein tyrosine phosphatasealpha and -beta (30), but their functional role in vivo is unknown. Together, this evidence suggests an in vivo role for VacA during pathogenesis.

There are multiple lines of in vitro evidence showing that VacA modulates host cell signal transduction and function. VacA is associated with the bacterial outer membrane and its secretion allows monomers of the toxin to assemble into hexamers or heptamers (31) in a process requiring acid activation (32). In the presence of host cells, VacA associates with plasma membrane microdomains, or lipid rafts, which are enriched in cholesterol and sphingolipids (33), and are becoming increasingly recognized as platforms for multiple pathogenic microbes to modulate host cell signalling (34). Whether putative VacA receptors also localize to membrane microdomains is unknown. Regardless, the toxin is internalized by cells in an actin-dependent process (35), where it is targeted to late endosomes (36), the Golgi apparatus and mitochondria (37). The toxin also inserts into the host cell plasma membrane to form anion-specific channels (38) that allow water to accumulate in the cell, contributing to the swelling phenotype observed during vacuolation (39). An increase in paracellular permeability of epithelial monolayers also results from treatment with VacA, which may provide a strategy for the bacterium to release nutrients from the host (40).

Phenotypically, VacA induces formation of numerous cytoplasmic vacuoles in host cells (41). These vacuoles exhibit an acidic microenvironment and express specific markers of late endosomes and lysosomes, the development of which are coordinated by the small GTPase Rab7 and, to a lesser extent, Rab5 (42). Functionally, in antigen-presenting cells, these vacuoles exhibit decreased proteolytic-dependent antigen processing capability (43). VacA binds to the intermediate filament VIP54, but the role of this interaction in vacuolation is not established (44).

In addition to vacuolation, VacA expression allows the bacterium to avoid endosomal fusion with the lysosome after phagocytosis (45). Toxin activity plays a role during induction of apoptosis in both epithelial cells (37) and macrophages (46). VacA also exerts effects on cells of the adaptive immune system, as VacA-induced p38 MAPK activity inhibits T-cell activation by suppressing nuclear factor of activated T-cell nuclear translocation (47). Furthermore, VacA inhibits epidermal growth factor-mediated signal transduction responses in KATO III gastric epithelial cells (48). Taken together, these observations indicate that this toxin exerts multiple effects on the host, including the ability to both activate and suppress host cell signal transduction responses.

\section{CAG PAI}

Sequencing of the $H$ pylori genome in 1997 (49) facilitated a closer look at the cag PAI, an approximately $40 \mathrm{~kb}$ segment of DNA integrated into the $H$ pylori chromosome that encodes about 30 genes (50). This PAI likely was acquired by horizontal transfer, as indicated by a guanine and cytosine content that is different from the remainder of the bacterial genome (35\% versus 39\% [49]) and by the transposable elements that flank its sequence (50). It is present only in some $H$ pylori strains and, thus, serves as a marker to classify strains, whereby type I strains carry the cag PAI and type II strains do not. Geographical variability exists in expression of the cag PAI by H pylori strains. Nonetheless, studies in both Mongolian gerbils (51) and humans $(21,52,53)$ suggest that the presence of the cag PAI correlates with more severe disease outcome in some populations. Although many functional responses by host cells to cag PAI-positive $H$ pylori have been documented in vitro (below), a lack of association between these responses and gastroduodenal disease in humans could be made (54). Whether this represents a true lack of association or, rather, an incomplete understanding of the interplay between bacterial, host and environmental factors, is unclear (54).

The precise functions of genes encoded on the cag PAI remains incompletely characterized. Deletion of the cag PAI reduces the ability of $H$ pylori to induce IL- 8 secretion from host cells (55). Some genes on the cag PAI also show similarity to known genes in Agrobacterium tumefaciens that encode a type IV secretion system (56), which is a filamentous bacterial surface appendage that can breach the host cell membrane to inject bacterial proteins (57). For example, cagE (formerly known as picB) shows homology to genes from other bacteria that code for a type IV secretion system ATPase, which likely provides energy for the secretion of bacterial proteins. Functionally, CagE expression is required to induce IL-8 secretion from host cells $(18,50,58)$. CagE also may be involved in the recruitment of Arp3 during $\mathrm{H}$ pyloriinduced cytoskeletal rearrangements resulting in epithelial cell elongation (17).

CagA, the product of another gene on the PAI, is the first and only substrate to date that has been shown to be injected into host cells by the type IV secretion system $(59,60)$. CagA is a $128 \mathrm{kDa}$ to $145 \mathrm{kDa}$ protein translocated into host cells where it is phosphorylated on tyrosine residues (60-63) by host cell Src kinase (64). Interestingly, the number of tyrosine residues on which CagA can be phosphorylated shows variation among strains, and more phosphorylation sites lead to increased CagA biological activity and association with disease (65). Functionally, CagA is implicated in cytoskeletal rearrangements (61) through binding Src homology-2-containing phosphatase (66) and dephosphorylation of host cell cytoskeletal proteins (67). CagA also binds to tight junction proteins, including zonula occludens 1 and junctional adhesion molecule to increase paracellular permeability of an epithelial monolayer (68). In addition, CagA affects host cell plasma membrane receptor activity. For instance, $\mathrm{CagA}$ is required to activate host cell heparin-binding epidermal growth factor-like growth 
factor by inducing matrix metalloproteinase activity, ultimately leading to activation of epidermal growth factor receptor signalling (69). Furthermore, CagA attaches to the hepatocyte growth factor receptor c-Met to induce epithelial cell scattering through activation of phospholipase $\mathrm{C}$ gamma and extracellular signal-regulated kinase 1/2 MAPK (70).

While understanding of CagA is improving, our knowledge of other Cag proteins is minimal. For example, $\mathrm{CagF}$ associates with the bacterial outer membrane and induces an antibody response from infected humans, but its precise function remains unknown (71). Isogenic mutants lacking CagG, CagL, $\mathrm{CagH}$, CagI or CagM all show a reduced capacity to stimulate DNA-binding activity of the host cell transcription factor AP-1 compared with the wild-type strain (72). Furthermore, CagG could be involved in bacterial adherence and the induction of IL-8 secretion (73), while CagP may be involved in adherence (74). Whether these Cag proteins are injected into the host cell and the precise signalling pathways they target remain to be defined.

In addition to characterizing the cag PAI, sequencing of genomes from two different $\mathrm{H}$ pylori strains showed that much of the genome was shared. However, a segment of DNA termed the plasticity region contains genes that are unique among strains (75). Similar to the cag PAI, this region displays a lower guanine and cytosine content than the rest of the genome, suggesting this region may also contain horizontally acquired PAIs (75). Knowledge of the genes encoded within the plasticity region is limited but growing. For example, genes coding for proteins with homology to type IV secretion system components unique from those encoded on the cag PAI have been localized to the plasticity region (76). Furthermore, a gene of unknown function found in the plasticity region, named JHP947, may be associated with duodenal ulcer and gastric cancer $(77,78)$. Thus, a more thorough examination of

\section{REFERENCES}

1. Meng G, Rutz M, Schiemann M, et al. Antagonistic antibody prevents toll-like receptor 2-driven lethal shock-like syndromes. J Clin Invest 2004;113:1473-81.

2. DuPont HL, Ericsson CD, Mathewson JJ, et al. Zaldaride maleate, an intestinal calmodulin inhibitor, in the therapy of travelers' diarrhea. Gastroenterology 1993;104:709-15.

3. Hommes D, van den Blink B, Plasse T, et al. Inhibition of stressactivated MAP kinases induces clinical improvement in moderate to severe Crohn's disease. Gastroenterology 2002;122:7-14.

4. Finlay BB, Falkow S. Common themes in microbial pathogenicity revisited. Microbiol Mol Biol Rev 1997;61:136-69.

5. Clyne M, Drumm B. Adherence of Helicobacter pylori to the gastric mucosa. Can J Gastroenterol 1997;11:243-8.

6. Evans DJ Jr, Evans DG. Helicobacter pylori adhesins: Review and perspectives. Helicobacter 2000;5:183-95.

7. Huesca M, Borgia S, Hoffman P, Lingwood CA. Acidic pH changes receptor binding specificity of Helicobacter pylori: A binary adhesion model in which surface heat shock (stress) proteins mediate sulfatide recognition in gastric colonization. Infect Immun 1996;64:2643-8.

8. Gobert AP, Bambou JC, Werts C, et al. Helicobacter pylori heat shock protein 60 mediates interleukin- 6 production by macrophages via a toll-like receptor (TLR)-2-, TLR-4-, and myeloid differention factor 88-independent mechanism. J Biol Chem 2004;279:245-50.

9. Clyne M, Dillon P, Daly S, et al. Helicobacter pylori interacts with the human single-domain trefoil protein TFF1. Proc Natl Acad Sci USA 2004;101:7409-14.

10. Hidaka E, Ota H, Hidaka H, et al. Helicobacter pylori and two ultrastructurally distinct layers of gastric mucous cell mucins in the surface mucous gel layer. Gut 2001;49:474-80.

11. Crowe SE, Alvarez L, Dytoc M, et al. Expression of interleukin 8 and gene products from the plasticity region, their effects on signal transduction and their association with disease is warranted in future studies.

\section{SUMMARY}

$H$ pylori infection modulates signal transduction pathways in multiple host cell types, and activation of certain cascades can be attributed to specific bacterial factors. Indeed, some redundancy exists whereby multiple $H$ pylori factors cause similar effects, such as induction of macrophage apoptosis by both CagA and VacA (46). On the other hand, infection can exert opposing effects, such as bacterial-induced NF- $\mathrm{KB}$ activity that is antiapoptotic (79). There are also instances whereby functional effects have yet to be associated with a specific bacterial factor, such as suppression of IL-4-induced signal transduction by $\mathrm{H}$ pylori infection (80), indicating a need for more work in the signal transduction area.

Future directions should employ multiple experimental techniques to characterize signalling pathways and functional outcomes modulated by $\mathrm{H}$ pylori infection. For example, signature tagged mutagenesis could reveal which $H$ pylori genes are important during infection in vivo (81). Also, a proteomic analysis of host cell protein expression induced during $H$ pylori infection, as was determined for enteropathogenic Escherichia coli (82), would be valuable in establishing functional outcomes of infection. Furthermore, future experiments should aim to determine the link between particular bacterial factors and the activation of specific signalling pathways and, ultimately, to clinical outcomes in infected individuals. Overall, such research provides a better understanding of the molecular mechanisms underlying chronic infectious disease, and may provide insight toward the development of therapeutic interventions based on knowledge of signal transduction.
CD54 by human gastric epithelium after Helicobacter pylori infection in vitro. Gastroenterology 1995;108:65-74.

12. Sharma SA, Tummuru MK, Miller GG, Blaser MJ. Interleukin-8 response of gastric epithelial cell lines to Helicobacter pylori stimulation in vitro. Infect Immun 1995;63:1681-7.

13. Maeda S, Yoshida H, Ogura K, et al. H pylori activates NF-kappaB through a signaling pathway involving IkappaB kinases, NF-kappaBinducing kinase, TRAF2, and TRAF6 in gastric cancer cells. Gastroenterology 2000;119:97-108.

14. Athman R, Philpott D. Innate immunity via Toll-like receptors and Nod proteins. Curr Opin Microbiol 2004;7:25-32.

15. Akira S. Toll-like receptor signaling. J Biol Chem 2003;278:38105-8.

16. Gewirtz AT, Yu Y, Krishna US, Israel DA, Lyons SL, Peek RM Jr. Helicobacter pylori flagellin evades toll-like receptor 5-mediated innate immunity. J Infect Dis 2004;189:1914-20.

17. Su B, Ceponis PJ, Lebel S, Huynh H, Sherman PM. Helicobacter pylori infection activates Toll-like receptor 4 expression in gastrointestinal epithelial cells. Infect Immun 2003;71:3496-502.

18. Tummuru MK, Sharma SA, Blaser MJ. Helicobacter pylori picB, a homologue of the Bordetella pertussis toxin secretion protein, is required for induction of IL-8 in gastric epithelial cells. Mol Microbiol 1995;18:867-76.

19. Maeda S, Akanuma M, Mitsuno Y, et al. Distinct mechanism of Helicobacter pylori-mediated NF-kappa B activation between gastric cancer cells and monocytic cells. J Biol Chem 2001;276:44856-64.

20. Guillemin K, Salama NR, Tompkins LS, Falkow S. Cag pathogenicity island-specific responses of gastric epithelial cells to Helicobacter pylori infection. Proc Natl Acad Sci USA 2002;99:15136-41.

21. Blaser MJ, Atherton JC. Helicobacter pylori persistence: Biology and disease. J Clin Invest 2004;113:321-33. 
22. Atherton JC, Cao P, Peek RM Jr, Tummuru MK, Blaser MJ, Cover TL. High prevalence of neutralizing activity to Helicobacter pylori cytotoxin in serum of gastric-carcinoma patients. Int J Cancer 1995;56:56-60.

23. Atherton JC, Peek RM Jr, Tham KT, Cover TL, Blaser MJ. Clinical and pathological importance of heterogeneity in vacA, the vacuolating cytotoxin gene of Helicobacter pylori. Gastroenterology 1997;112:92-9.

24. Go MF, Cissell L, Graham DY. Failure to confirm association of vacA gene mosaicism with duodenal ulcer disease. Scand J Gastroenterol 1998;33:132-6.

25. Benenson S, Halle D, Rudensky B, et al. Helicobacter pylori genotypes in Israeli children: The significance of geography. J Pediatr Gastroenterol Nutr 2002;35:680-4.

26. Hirai M, Azuma T, Ito S, Kato T, Kohli Y, Fujiki N. High prevalence of neutralizing activity to Helicobacter pylori cytotoxin in serum of gastric-carcinoma patients. Int J Cancer 1994;56:56-60.

27. Salama NR, Otto G, Tompkins L, Falkow S. Vacuolating cytotoxin of Helicobacter pylori plays a role during colonization in a mouse model of infection. Infect Immun 2001;69:730-6.

28. Telford JL, Ghiara P, Dell'Orco M, et al. Gene structure of the Helicobacter pylori cytotoxin and evidence of its key role in gastric disease. J Exp Med 1994;179:1653-8.

29. Fujikawa A, Shirasaka D, Yamamoto S, et al. Mice deficient in protein tyrosine phosphatase receptor type $\mathrm{Z}$ are resistant to gastric ulcer induction by VacA of Helicobacter pylori. Nat Genet 2003;33:375-81. (Erratum in 2003;33:533).

30. Yahiro K, Wada A, Nakayama M, et al. Protein-tyrosine phosphatase alpha, RPTP alpha, is a Helicobacter pylori VacA receptor. J Biol Chem 2003;278:19183-9.

31. Lupetti P, Heuser JE, Manetti R, et al. Oligomeric and subunit structure of the Helicobacter pylori vacuolating cytotoxin. J Cell Biol 1996;133:801-7.

32. de Bernard M, Papini E, de Filippis V, et al. Low pH activates the vacuolating toxin of Helicobacter pylori, which becomes acid and pepsin resistant. J Biol Chem 1995;270:23937-40.

33. Schraw W, Li Y, McClain MS, van der Goot FG, Cover TL. Association of Helicobacter pylori vacuolating toxin (VacA) with lipid rafts. J Biol Chem 2002;277:34642-50.

34. Lafont F, Abrami L, van der Goot FG. Bacterial subversion of lipid rafts. Curr Opin Microbiol 2004;7:4-10.

35. Ricci V, Galmiche A, Doye A, Necchi V, Solcia E, Boquet P. High cell sensitivity to Helicobacter pylori VacA toxin depends on a GPIanchored protein and is not blocked by inhibition of the clathrinmediated pathway of endocytosis. Mol Biol Cell 1999;11:3897-909.

36. Molinari M, Galli C, Norais N, et al. Vacuoles induced by Helicobacter pylori toxin contain both late endosomal and lysosomal markers. J Biol Chem 1997;272:25339-44.

37. Galmiche A, Rassow J, Doye A, et al. The $\mathrm{N}$-terminal $34 \mathrm{kDa}$ fragment of Helicobacter pylori vacuolating cytotoxin targets mitochondria and induces cytochrome c release. EMBO J 2000;19:6361-70.

38. Szabo I, Brutsche S, Tombola F, et al. Formation of anion-selective channels in the cell plasma membrane by the toxin VacA of Helicobacter pylori is required for its biological activity. EMBO J 1999;18:5517-27.

39. Morbiato L, Tombola F, Campello S, et al. Vacuolation induced by VacA toxin of Helicobacter pylori requires the intracellular accumulation of membrane permeant bases, $\mathrm{Cl}(-)$ and water. FEBS Lett 2001;508:479-83.

40. Papini E, Satin B, Norais N, et al. Selective increase of the permeability of polarized epithelial cell monolayers by Helicobacter pylori vacuolating toxin. J Clin Invest 1998;102:813-20.

41. Leunk RD, Johnson PT, David BC, Kraft WG, Morgan DR. Cytotoxic activity in broth-culture filtrates of Campylobacter pylori. J Med Microbiol 1998;26:93-9.

42. Papini E, Satin B, Bucci C, et al. The small GTP binding protein rab7 is essential for cellular vacuolation induced by Helicobacter pylori cytotoxin. EMBO J 1997;16:15-24.

43. Molinari M, Salio M, Galli C, et al. Selective inhibition of Ii-dependent antigen presentation by Helicobacter pylori toxin VacA. J Exp Med 1998;187:135-40.

44. de Bernard M, Moschioni M, Napolitani G, Rappuoli R, Montecucco C. The VacA toxin of Helicobacter pylori identifies a new intermediate filament-interacting protein. EMBO J 2000;19:48-56.

45. Zheng PY, Jones NL. Helicobacter pylori strains expressing the vacuolating cytotoxin interrupt phagosome maturation in macrophages by recruiting and retaining TACO (coronin 1) protein. Cell Microbiol 2003;5:25-40.

46. Menaker RJ, Ceponis PJ, Jones NL. Helicobacter pylori induces apoptosis of macrophages in association with alterations in the mitochondrial pathway. Infect Immun 2004;72:2889-98.

47. Gebert B, Fischer W, Weiss E, Hoffmann R, Haas R. Helicobacter pylori vacuolating cytotoxin inhibits $\mathrm{T}$ lymphocyte activation. Science 2003;301:1099-102

48. Pai R, Wyle FA, Cover TL, Itani RM, Domek MJ, Tarnawski AS. Helicobacter pylori culture supernatant interferes with epidermal growth factor-activated signal transduction in human gastric KATO III cells. Am J Pathol 1998;152:1617-24.

49. Tomb JF, White O, Kerlavage AR, et al. The complete genome sequence of the gastric pathogen Helicobacter pylori. Nature 1998;388:539-47. (Erratum in 1997;389:412).

50. Censini S, Lange C, Xiang Z, et al. cag, a pathogenicity island of Helicobacter pylori, encodes type I-specific and disease-associated virulence factors. Proc Natl Acad Sci USA 1996;93:14648-53.

51. Ogura K, Maeda S, Nakao M, et al. Virulence factors of Helicobacter pylori responsible for gastric diseases in Mongolian gerbil. J Exp Med 2000;192:1601-10.

52. Parsonnet J, Friedman GD, Orentreich N, Vogelman H. Risk for gastric cancer in people with $\mathrm{Cag} \mathrm{A}$ positive or CagA negative Helicobacter pylori infection. Gut 1997;40:297-301.

53. Huang JQ, Zheng GF, Sumanac K, Irvine EJ, Hunt RH. Metaanalysis of the relationship between cagA seropositivity and gastric cancer. Gastroenterology 2003;125:1636-44.

54. Backert S, Schwarz T, Miehlke S, et al. Functional analysis of the cag pathogenicity island in Helicobacter pylori isolates from patients with gastritis, peptic ulcer, and gastric cancer. Infect Immun 2004;72:1043-56.

55. Akopyants NS, Clifton SW, Kersulyte D, et al. Analyses of the cag pathogenicity island of Helicobacter pylori. Mol Microbiol 1998;28:37-53.

56. Nagai H, Roy CR. Show me the substrates: Modulation of host cell function by type IV secretion systems. Cell Microbiol 2003;5:373-83.

57. Tanaka J, Suzuki T, Mimuro H, Sasakawa C. Structural definition on the surface of Helicobacter pylori type IV secretion apparatus. Cell Microbiol 2003;5:395-404.

58. Day AS, Jones NL, Lynett JT, et al. cagE is a virulence factor associated with Helicobacter pylori-induced duodenal ulceration in children. J Infect Dis 2000;181:1370-5.

59. Stein M, Rappuoli R, Covacci A. Tyrosine phosphorylation of the Helicobacter pylori CagA antigen after cag-driven host cell translocation. Proc Natl Acad Sci USA 2000;97:1263-8.

60. Odenbreit S, Puls J, Sedlmaier B, Gerland E, Fischer W, Haas R. Translocation of Helicobacter pylori CagA into gastric epithelial cells by type IV secretion. Science 2000;287:1497-500.

61. Segal ED, Cha J, Lo J, Falkow S, Tompkins LS. Altered states: Involvement of phosphorylated CagA in the induction of host cellular growth changes by Helicobacter pylori. Proc Natl Acad Sci USA 1999;96:14559-64.

62. Asahi M, Azuma T, Ito S, et al. Helicobacter pylori CagA protein can be tyrosine phosphorylated in gastric epithelial cells. J Exp Med 2000;191:593-602.

63. Backert S, Moese S, Selbach M, Brinkmann V, Meyer TF. Phosphorylation of tyrosine 972 of the Helicobacter pylori CagA protein is essential for induction of a scattering phenotype in gastric epithelial cells. Mol Microbiol 2001;42:631-44.

64. Selbach M, Moese S, Hauck CR, Meyer TF, Backert S. Src is the kinase of the Helicobacter pylori CagA protein in vitro and in vivo. J Biol Chem 2002;277:6775-8.

65. Higashi H, Tsutsumi R, Fujita A, et al. Biological activity of the Helicobacter pylori virulence factor CagA is determined by variation in the tyrosine phosphorylation sites. Proc Natl Acad Sci USA 2002;99:14428-33.

66. Higashi H, Tsutsumi R, Muto S, et al. SHP-2 tyrosine phosphatase as an intracellular target of Helicobacter pylori CagA protein. Science 2002;295:683-6.

67. Selbach M, Moese S, Hurwitz R, Hauck CR, Meyer TF, Backert S. The Helicobacter pylori CagA protein induces cortactin dephosphorylation and actin rearrangement by c-Src inactivation. EMBO J 2003;22:515-28

68. Amieva MR, Vogelmann R, Covacci A, Tompkins LS, Nelson WJ, Falkow S. Disruption of the epithelial apical-junctional complex by Helicobacter pylori CagA. Science 2003;300:1430-4. 
69. Keates S, Sougioultzis S, Keates AC, et al. cag+ Helicobacter pylori induce transactivation of the epidermal growth factor receptor in AGS gastric epithelial cells. J Biol Chem 2001;276:48127-34.

70. Churin Y, Al-Ghoul L, Kepp O, Meyer TF, Birchmeier W, Naumann M. Helicobacter pylori CagA protein targets the c-Met receptor and enhances the motogenic response. J Cell Biol 2003;161:249-55

71. Seydel A, Tasca E, Berti D, Rappuoli R, Del Giudice G, Montecucco C. Characterization and immunogenicity of the $\mathrm{CagF}$ protein of the cag pathogenicity island of Helicobacter pylori. Infect Immun 2002;70:6468-70

72. Meyer-ter-Vehn T, Covacci A, Kist M, Pahl HL. Helicobacter pylori activates mitogen-activated protein kinase cascades and induces expression of the proto-oncogenes c-fos and c-jun. J Biol Chem 2000;275:16064-72.

73. Mizushima T, Sugiyama T, Kobayashi T, et al. Decreased adherence of cagG-deleted Helicobacter pylori to gastric epithelial cells in Japanese clinical isolates. Helicobacter 2002;7:22-9.

74. Zhang ZW, Dorrell N, Wren BW, Farthingt MJ. Helicobacter pylori adherence to gastric epithelial cells: A role for non-adhesin virulence genes. J Med Microbiol 2002;51:495-502.

75. Alm RA, Ling LS, Moir DT, et al. Genomic-sequence comparison of two unrelated isolates of the human gastric pathogen Helicobacter pylori. Nature 1999;397:176-80. (Erratum in 1999;397:719).

76. Kersulyte D, Velapatino B, Mukhopadhyay AK, et al. Cluster of type IV secretion genes in Helicobacter pylori's plasticity zone. J Bacteriol 2003; 185:3764-72.

77. Occhialini A, Marais A, Alm R, Garcia F, Sierra R, Megraud F. Distribution of open reading frames of plasticity region of strain $\mathrm{J99}$ in Helicobacter pylori strains isolated from gastric carcinoma and gastritis patients in Costa Rica. Infect Immun 2000;68:6240-9.

78. Santos A, Queiroz DM, Menard A, et al. New pathogenicity marker found in the plasticity region of the Helicobacter pylori genome. J Clin Microbiol 2002;41:1651-5.

79. Yanai A, Hirata Y, Mitsuno Y, et al. Helicobacter pylori induces antiapoptosis through nuclear factor-kappaB activation. J Infect Dis 2003;188:1741-51.

80. Ceponis PJ, McKay DM, Menaker RJ, Galindo-Mata E, Jones NL. Helicobacter pylori infection interferes with epithelial Stat6-mediated interleukin-4 signal transduction independent of cagA, cagE, or VacA. J Immunol 2003;171:2035-41.

81. Mecsas J. 2002. Use of signature-tagged mutagenesis in pathogenesis studies. Curr Opin Microbiol 2002;5:33-7.

82. Hardwidge PR, Rodriguez-Escudero I, Goode D, et al. Proteomic analysis of the intestinal epithelial cell response to enteropathogenic Escherichia coli. J Biol Chem 2004;279:20127-36.

83. Gold BD, Huesca M, Sherman PM, Lingwood CA. Helicobacter mustelae and Helicobacter pylori bind to common lipid receptors in vitro. Infect Immun 1993;61:2632-8.

84. Valkonen KH, Ringner M, Ljungh A, Wadstrom T. High-affinity binding of laminin by Helicobacter pylori: Evidence for a lectin-like interaction. FEMS Immunol Med Microbiol 1993;7:29-37.

85. Ilver D, Arnqvist A, Ogren J, et al. Helicobacter pylori adhesin binding fucosylated histo-blood group antigens revealed by retagging. Science 1998;279:373-7.

86. Linden S, Nordman H, Hedenbro J, Hurtig M, Boren T, Carlstedt I. Strain- and blood group-dependent binding of Helicobacter pylori to human gastric MUC5AC glycoforms. Gastroenterology 2002;123:1923-30. (Erratum in 2003;124:588).

87. Van de Bovenkamp JH, Mahdavi J, Korteland-Van Male AM, et al. The MUC5AC glycoprotein is the primary receptor for Helicobacter pylori in the human stomach. Helicobacter 2003;8:521-32.

88. Mahdavi J, Sonden B, Hurtig M, et al. Helicobacter pylori SabA adhesin in persistent infection and chronic inflammation. Science 2002;297:573-8. 


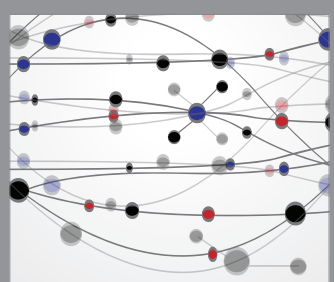

The Scientific World Journal
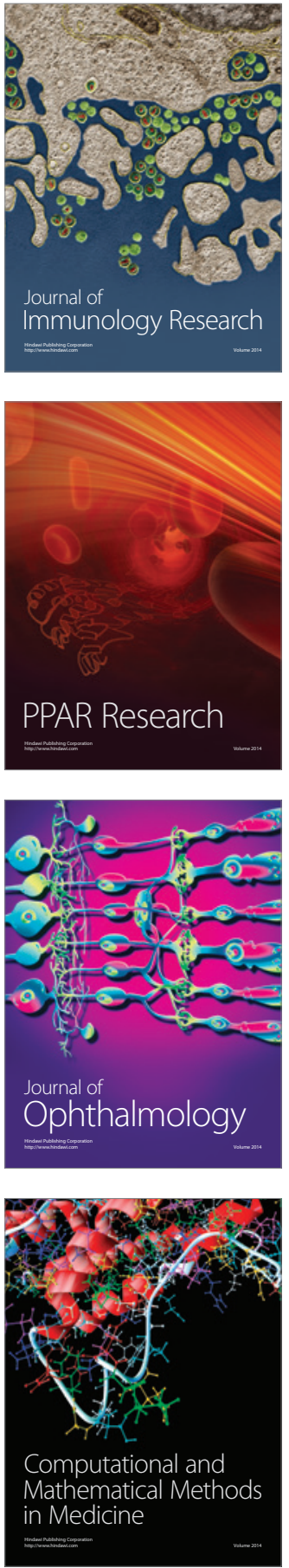

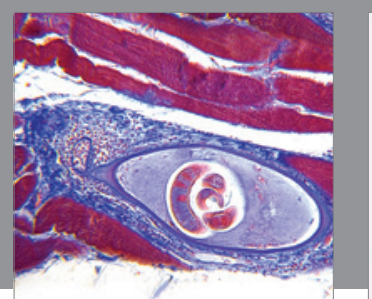

Gastroenterology Research and Practice

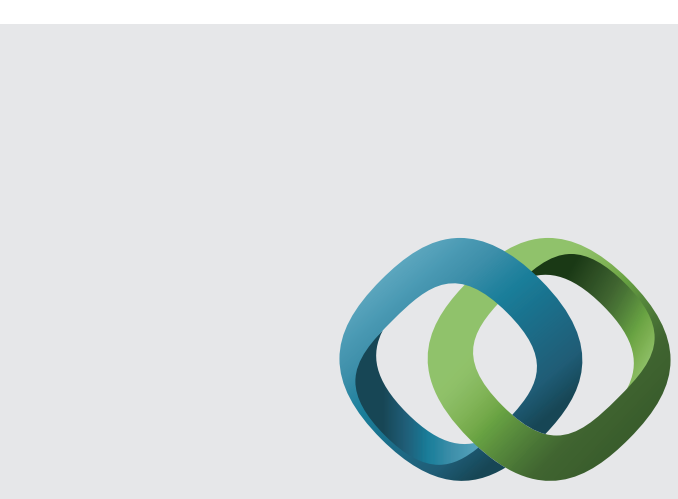

\section{Hindawi}

Submit your manuscripts at

http://www.hindawi.com
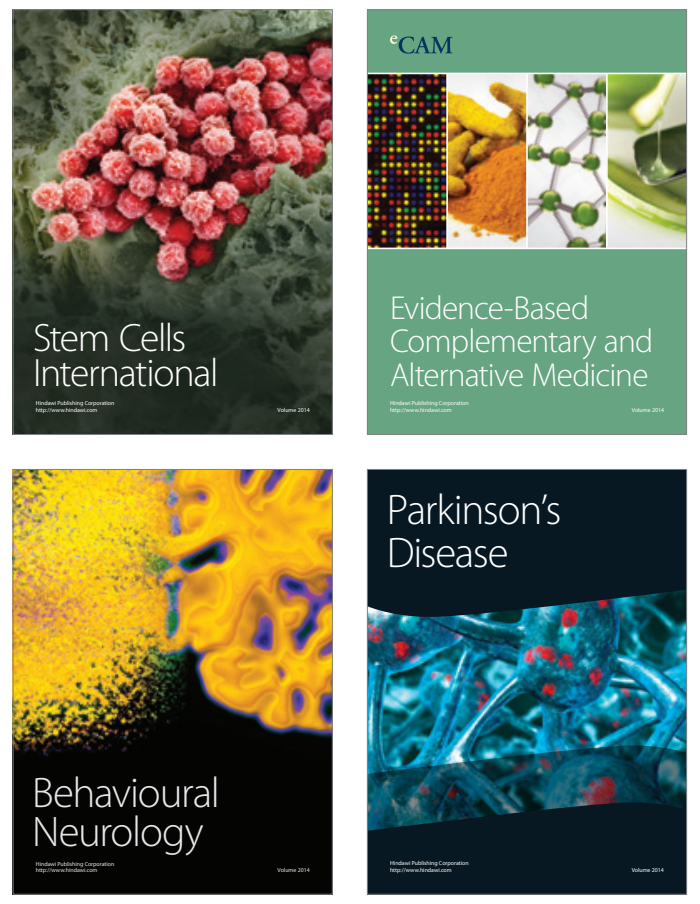
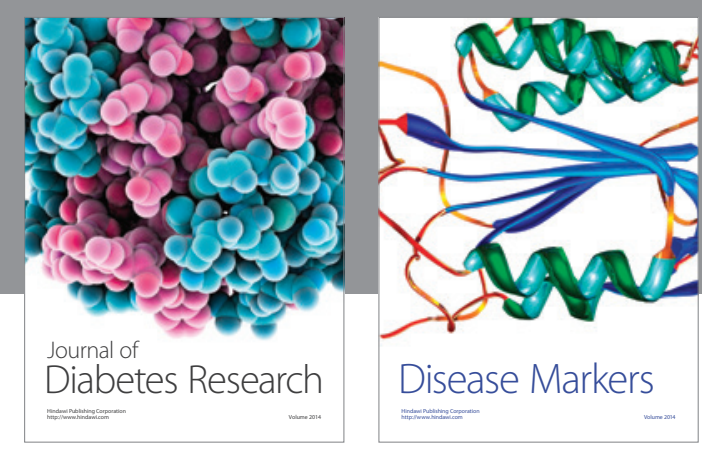

Disease Markers
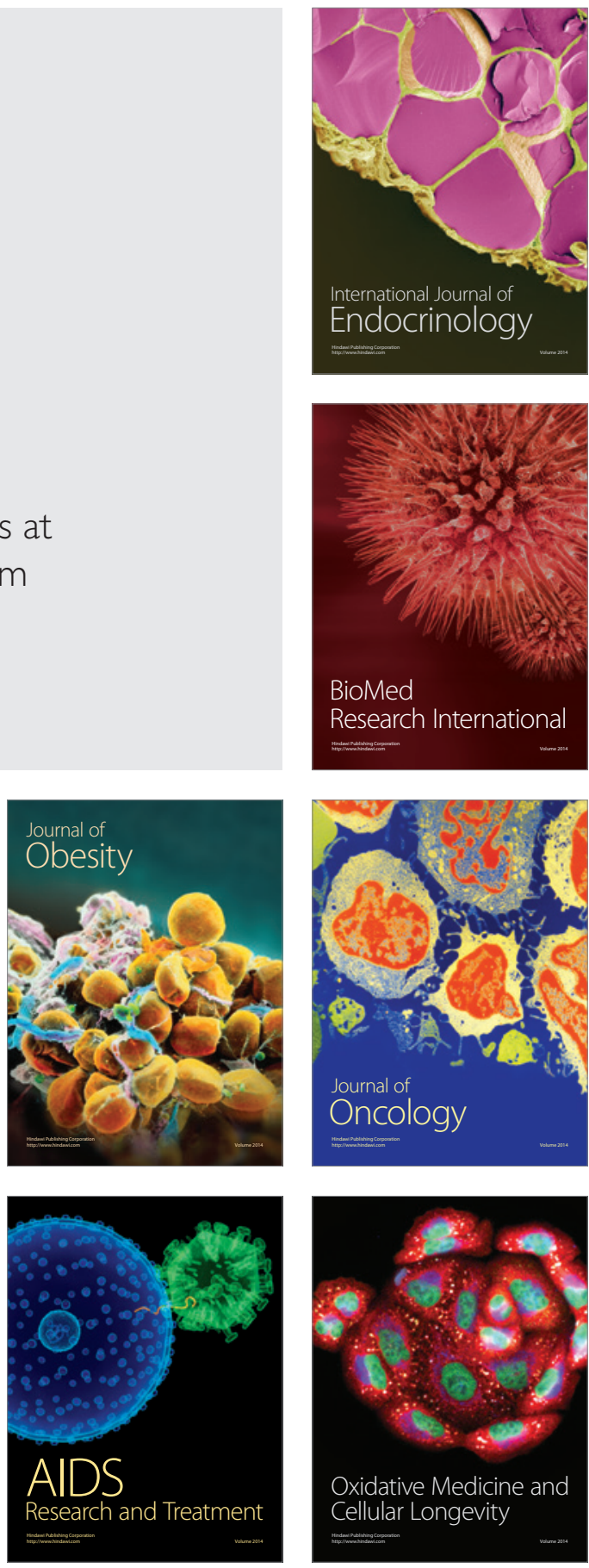